\title{
Effect of Human Capital Expenditure on the Profitability of Quoted Manufacturing Companies in Nigeria
}

\author{
Olowolaju, Philip Segun \\ Department of Accounting, \\ Federal University of Technology, Akure, Nigeria \\ P. O. Box 297, Akure, Nigeria.
}

Tel: 234-803-352-4368_E-mail: olowosegun2014@gmail.com

\author{
Oluwasesin, Olayemi Deborah \\ Centre for Continuing Education \\ Federal University of Technology, Akure, Nigeria
}

Tel: 234-803-439-2248Ｅ- mail: yemifiaji@yahoo.com

Received: June 19, 2016 Accepted: July 22, $2016 \quad$ Published: December 1, 2016

doi:10.5296/ajfa.v8i2.10197 URL: http://dx.doi.org/10.5296/ajfa.v8i2.10197

\begin{abstract}
The study examined the effect of human capital on the profitability of quoted manufacturing companies in Nigeria. The study aimed at determining if expenditure on human has influence on the profitability of listed manufacturing companies on the Nigeria Stock Exchange. A sample of 10 listed manufacturing companies on the Nigeria Stock Exchange was used for the study. This study used data mainly from secondary sources and the analysis of data collected was done using descriptive and inferential statistics. The descriptive statistics include mean, standard deviation, kurtosis, skewness while inferential statistics that was used in testing the hypotheses include panel regression and correlation. The study revealed that all the explanatory variables have positive relationship with profitability, however, expenditure on health contributed more to the profitability of the firms with a beta value of 27.8609 than expenditures on salaries and wages, training and contributory pension with beta values of $0.3107,2.6752$ and 3.4519 respectively. The study also found that that only expenditure on health can significantly predict net profit at 5\% level of significance. The study concluded that human capital expenditure significantly influenced profitability of manufacturing
\end{abstract}




\section{Macrothink}

Asian Journal of Finance \& Accounting ISSN 1946-052X

companies quoted on the Nigerian Stock Exchange and companies that place more emphasis on human capital, maintaining it and treating it as a pure asset will have motivated work force.

Keywords: Human capital, Expenditure, Profitability, Manufacturing, Companies 


\section{Introduction}

Despite the advent of information technology which has made the whole world to become a global village, human intellect is still the brain behind its success. There is no technological or service base evolution however sound it may be, that has not and will not be driven by human intellect which is the ability, knowledge and skill of such an individual. For companies to seek new ways of developing and maintaining competitive advantage in the present dynamic environment, it is important that firms truly leverage on their workforce as a competitive weapon. To leverage on the workforce means an improvement largely on the procurement of the right people with high level of intellectual competence, hence the need for expenditure on human capital.

Basically, the concept of human capital expenditure arose from the transformation of individual competence into highly productive human capital with the effective input of education, health and moral value. Human capital is the mixture of human and capital. In the economic perspective, the capital refers to factors of production used to create goods and services that are not themselves significantly consumed in the production process. Along with the meaning of capital in the economic perspective, Boldizzoni (2008) stressed that the human is the subject to take charge of all economic activities such as production and consumption.

Therefore, it can be deduced that human capital means one of the production elements that can generate added value through inputting it. On the other hand, expenditure is the sacrifice incurred for the procurement of some anticipated benefits. However, for the purpose of this study, such expenditure is incurred by the organizations selected for the study on the procurement of human capital, which can be revenue or capital in nature.

Organizations' survival, growth and profitability are dependent more on intellectual assets than physical assets. Today, human capital is perceived to be a resource that requires strategic attention. Therefore, clear estimation of expenditure on it has gained significant importance (Ifrueze, 2014), This present century is knowledge driven, it is therefore necessary for organizations to utilize its human capital in such a way that will not make its success to be at stake. This can be achieved by ensuring that the human capital that will drive the economy be recognized as a valuable part of the total value of an organization in order to assess the effect it has on the corporate profitability.

The recent challenge of globalization in the Nigeria economy is gradually shifting most of the quoted manufacturing companies to customer oriented organizations where knowledge, skill and attitude count. This has given rise to importance in the way organizations invest on the human capital which runs them, largely because many organizations' expenditure on human capital has risen faster than those of non-human capital (World Economic Forum 2015). An upward shift in the organization's expenditure on human capital, has led to an increased demand for its inclusion in the financial report to measure it effect on the overall profitability of quoted companies. 
Besides, most organisations increase the staff salaries and wages in order to motivate them and to ensure they put in their best for the achievement of the organizational goals. These efforts are expected to affect their profitability if the cost incurred will not be a waste

The rate of increase in human capital expenditure to train and retrain quality staff in many of these quoted companies appears not to be commensurate with the rate of growth in their profitability. Thus, the objective of this study is to assess the effect of human capital expenditure on the profitability of selected quoted manufacturing companies in Nigeria,

\subsection{Conceptual Framework}

The concept of human capital was first developed by Sir Williams Pretty in the year 1691 but the research into human capital began in 1960 by Rensis Likert. With the emergence of classical economics, a scientific theory on human capital was later developed (Fitzsimons, 1999). After the manifestation of that concept as a theory, human capital began to develop as an academic field which prompted some researchers to expansively clarify how the expenditure on such human capital could affect profitability. Ismaila (2013) recognised human capital as a significant factor for the sustainability of companies in the emerging knowledge based economy.

The concept of human capital has been variously categorized from different perspectives in the academic fields. The first aspect is from the individual point of view. Schultz (1961) recognized the human capital as 'something akin to property' against the concept of labour force in the classical perspective. It can be deduced from his view that human capital is knowledge, skill, attitude and ability acquired through training and embedded in an individual. Baker (2012) conceptualized human capital as the loop that linked together the knowledge, abilities, skills, experiences and creation owned by the members of the organization.

The second view point is on the accumulation process of human capital itself. The stock of human capital is accumulated through the process of education and training. The educational process ranges from compulsory education, vocational education and tertiary education. The training aspect can be acquired through employer-sponsored training, self-sponsored training or training acquired through individual experience (Alan, 2008).

The third view on human capital is closely linked to the production-oriented aspect of human capital. Rosen (1999) states the human capital as 'an investment that people make in themselves to increase their productivity'. More recently, Frank and Bemanke (2007) defined human capital to be 'an amalgam of factors such as education, experience, training, intelligence, energy, work habits, trustworthiness, and initiative that affect the value of a worker's marginal product'. From these perspectives, one can conclude that economic benefit can be generated through making use of the stock of skills, knowledge and abilities embedded in an individual to perform. Also, Rodriguez and Loomis (2007) define human capital as 'the knowledge, skills, competences and attributes in individuals that facilitates the creation of personal, social and economic well being.

In defining the concept of human capital, greater importance has to be given to education and training. This is because education and training are instrumental to the outcome of human 
capital which is uniqueness and value. Therefore, in order to dependently or independently generate the uniqueness and values embedded in human capital, learning through education and training must be given higher preference. Kwon (2010) characterized human capital as; expandable, self-generating, transportable and shareable. The expandable and self-generating characteristics of human capital can be said to mean the possibility that the stock of knowledge increases individual human capital. While the transportable and shareable characteristics can be likened to the ability of an individual to be able to impact the knowledge acquired into others in form of training.

\subsection{Theoretical Framework}

Human capital as the knowledge based economy has its roots from the field of macroeconomic theory. Becker (1976) developed the theory by identifying employees in the organization as human capital which allows them to be highly valued. He thereby divided human capital into general human capital and firm specific human capital which for the first time provided a comparative insight into the incentives for the accumulation of capabilities. Davenport (1999) supported Becker's theory in that it permits the model where employees are 'investors in a business, paying in human capital and expecting a return on their investment'. They also relate the rate of return on human capital to investment in education and training which is also a key factor that influences the competitiveness of firms.

Schmidt (2004) defined human capital as a form intangible asset that creates future economic value which includes the competencies of frontline employees and organizational capabilities. Human capital theory encompasses many components but essentially describing the quality of the labour force. Schultz (1961) in his own notion of human capital theory, conceives that human capital is the result of investment, and so it value is the expenditure that is invested to enhance ability.

Furthermore, Tseng and GooWang (2005) viewed human capital to be a holistic output, which is the total value of personal physical strength, intelligence, knowledge and skills for utilization. The total output is the sum of labour abilities of a particular population. Therefore, going by the above views on the theory of human capital, it can be deduced that human capital is the labour ability (skill, strength, knowledge, and expertise) of any person in terms of output which is as a result of investment and the worth of such an individual.

From the perspective of classical economic theory, human capital is considered as labour and as a commodity that can be traded in terms of purchase and sale. Traditionally, human capital is associated with labour. Unlike the traditionally meaning, human capital refers to the ability, expertise, knowledge and skills possessed by an individual, especially those acquired through education, training and development that enhance the potential economic value of such an individual. Human capital as separated by Becker (1976) has two major divisions; the firm-specific human capital and the general purpose human capital. According to OECD World Forum (2009), the firm-specific human capital is accumulated through education and training tailored towards a particular task which will probably give the firm outstanding performance and in turn bring about competitive advantage over others. While the general purpose human capital on the other hand is the basic knowledge and skill that is useful to a 
variety of firms, not specific to a task or company and can be accumulated through education or working experience. Emphasizing the social and economic importance of human capital theory, Kwon (2010) noted that the most valuable of all capital is that of investing in human being through education, training, health and development.

The theory of human capital brings about expenditure on human capital. Expenditures on human capital such as; education, training and development are not just ordinary cost in the course of running an organisation, but an investment from which valuable returns that can be calculated are expected. It is an important agent for boosting organizations profitability. This study capitalized on this theory by emphasizing that expenditure on human capital becomes an integral (that is, essential) part of the profitability of quoted manufacturing companies.

\subsection{Empirical Framework}

Realizing the importance of human capital as a valuable resource for innovation, enhancement and maintenance of organizational competitive advantage and at the same time improving its corporate image in the global market, many researchers in Nigeria, United states, Europe, United Kingdom, Australian, China, Denmark, India, Finland, Kujansiva and some other countries all over the world have conducted intensive research on various aspects of human capital expenditure. One of the best examples is that of the Denmark Government (Danish Memo 2004). The Danish Ministry of Business and Industry issued a directive that with effect from the trading year 2005, all companies registered in Denmark would be required to include in their annual reports information on human capital expenditure. A minimum of five measures for each was required and comparison with the previous two years must be shown. Figure for investment in human asset must be shown and compared with the previous two years. A narrative should accompany each set of figures. Information for investors about human capital both current and future should occupy at least one third of their report. Demos and Leadbeater (2009) reported that few companies in Europe have measured and reported on their human capital cost. Also, their study conducted on companies in the United Kingdom, revealed that methods used to measure expenditure on human capital depend on which user group the result was meant for. Roslender and Fincham ( 2011) affirms that few companies like Bhel, Inlosys and Reliance industries in India have implemented accounting for human capital expenditure and some are working on it.

\subsubsection{Relationship between Human Capital Expenditure and Corporate Profitability}

The relationship between human capital expenditure and corporate profitability can be assessed by classifying the two variables into dependent and independent variables. The human capital expenditure is the independent variable while profitability is the dependent variable. The profitability of a quoted company is a function of its human capital and the quality of the human capital is also a function of Training and Development (T\&D) which is a cost to the organization. Some recent researchers have argued whether the human capital cost and profitability of quoted companies are of positive or negative relationship. Maimuna (2009) analysed the positive relationship between human capital expenditure and profitability in that expenditure on education, training and development increased productivity over twice the size of the wage increase of the trainee. This is because not all productivity gain brought 
about by training is compensated by increase in individual remuneration thereby making such investment remains profitable for organizations. Gene (2008), a chief executive officer of Capital Analytics Consulting Firm based in North Carolina, United State of America (USA) gave analyses of ConAgra foods Inc. based in the United States of America. He emphasized the positive impact of a new leadership initiative by studying the overall twelve months turnover of supervisors that underwent training which translated to a saving of \$2.3 million in the first year of new leadership initiative. He further explained how training also increased audit scores at the company's smaller plant to 8.9 up from 7.3 on a scale of 10 .

Some recent researchers, Salman and Tayib (2013) examined the interaction between expenditure on human capital and financial performance of 50 public listed companies in Nigeria and provide evidence of interaction between the two variables which further revealed that expenditure on human capital influence performance of the sampled companies positively. Ahangar (2011) and Okwy and Christopher (2010) found human capital to be relevant in both companies financial performance and future benefits using cost models and economic approaches. However, Shrader and Siegal (2007) remarked that human capital concept are like other assets since they are acquired to generate future profits, hence they should be treated as other assets and be considered when valuing a company by capitalizing them instead of expensing them in the current period. They maintained that there is the need for companies to disaggregate human capital cost as revenue and capital cost and report it with other assets despite the difficulty in quantifying the value, expertise knowledge, skills and competences of human capital. The constraint of separating the cost relating to human capital into its revenue and capital expenditure element was also noted. This is because it will in not measure increase profitability, net worth and market value. Chang and Hseih (2011) using the Value Added Intellectual Co-efficient Model(VAICM) found expenditure on human capital to have strong correlation in both company performance and market capitalisation of the companies selected for the study in China. Temitope and Abdulbakar (2014) in their studies provided empirical evidence of significant relationship between the human capital and profitability of some of the sampled Nigerian companies on which the studies were conducted. On the other hand, they found some Nigerian sampled companies having no or weak correlation between the two variables.

2.3.2 Classification of Human Capital Expenditure and Its Effect on Profitability of Quoted Manufacturing Companies in Nigeria

Classifying human capital expenditure in quoted manufacturing companies seems to have significant effect on their profitability. These can be analysed from the short run effect and the long run effect. Onafaluyo, Eke and Akinlabi (2011) cited in Anuonye (2015) restate the short run and long run effect of classifying human capital expenditure. Looking at the short run effect, if an organization is starting operation newly, the cost incurred to procure staff, train them and pay their salaries may not initially translate to profit. In fact, it may end up with the organization incurring losses all because there is tendency of using up more cash than they earn. But the long run effect on the other hand, start showing as the organisation is growing and having competitive advantage over others which can be through cost leadership or differentiation. Cost leadership is when organization reduces its cost to ensure that it 
becomes the lowest-cost producer. Differentiation means when a company uses some strategies to make its producst or services to be considered by customers as different from those of its competitors. Also, the profit will increase tremendously when the manufacturing company becomes a star in the market. To be a star in the market means to have a high relative market share and a high growth market. All these long run achievements do not just come, but as a result of that which the organization has invested in the human capital that runs the organization.

To make clear the inclusion of expenditure on human capital in the financial statement and to ensure accounting for it, Ifurueze (2013) opined that from the International Financial Reporting Standard (IFRS), human capital expenditure should be classified into either capital expenditure or revenue expenditure. The classification adopted by an organization will determine its effect on the profitability of such organization. Some organization capitalizes the substantial part of their training expenditure because they believe that the benefit of the training will accrue for some years. When this classification is adopted it will increase the profitability as the training cost will be spread over a number of years for which the training benefit is to accrue on human capital and must be treated differently.

Capital expenditure should be capitalized and recorded in the statement of financial position as intangible assets and amortised over the useful life of the human asset. The amortised value should be recorded as expenses in the statement of comprehensive income. However, revenue expenditure is charged to expenses in the statement of profit or loss. The capital expenditure will be treated as investment in human capital asset under intangible asset according to International Accounting Standards (IAS38) and are expected to be recognized in the financial statement. Mirvis and Macy (1976) cited in Ifrueze (2013) analysed the logic behind this treatment to be the development cost which provides benefits beyond the current accounting period. Odesa (2014), also acknowledged the effect of classification on profitability to some users of the financial statement who need information about the human capital asset of the organisation such as; investors and managers. Investors are the existing and potential shareholders of a company who need the information about the value of human resource assets of the organization to assist them in making decision to acquire, retain or disposed off stock of the organization because human asset is the lifeline of the future of an organization. While managers are those that ensure smooth running of the organization and ensure that human capital are efficiently invested to enhance future earning power of the organization. Charging this investment to the statement of comprehensive income as expense will produce relatively lower net profit in the current year.

\section{Research Method}

The study was analytical in nature and panel regression was employed to look at the relationship of human capital expenditure on the profitability of quoted companies in the manufacturing sector .The total manufacturing companies listed on the Nigeria Stock Exchange as at $31^{\text {st }}$ Dec 2014, were forty-five (45) in number which covers manufacturing activities in eight (8) sectors of the economy. A sample of ten (10) companies was purposively selected for the study and the study covered a period of (Ten) 10 years from 2005 


\section{Macrothink}

to 2014. Data was collected from the published financial statements of the companies selected for the study.

\subsection{Model Specification and Measurement of Variables}

Being a study on manufacturing companies, cost model was adopted which was premised on the assessment of human capital expenditure on profitability of quoted companies. This study established empirical evidence that expenditure on human capital can have effect on the profitability of the firms. Therefore, the functions below represent the relationship.

$$
\mathrm{PBT}=\mathrm{f}(\mathrm{THCE})
$$

Where: PBT $=$ Profit before tax

\section{THCE $=$ Total Human Capital Expenditure}

The function above can be written as a model thus:

$$
\mathrm{PBT}=\beta_{\mathrm{o}}+\beta_{1} \mathrm{SW}+\beta_{2} \mathrm{TR}+\beta_{3} \mathrm{CP}+\beta_{4} \mathrm{H}+\mu--(\text { Basic Model })
$$

$$
\begin{aligned}
& \text { PBT }=\text { Profit before tax } \\
& \text { SW }=\text { Salaries and Wages } \\
& \text { TR }=\text { Training } \\
& \text { CP }=\text { Contributory Pension } \\
& \text { HT }=\text { Health } \\
& \mu=\text { Error term }
\end{aligned}
$$

\section{Results and Discussion}

The study sought to determine the relationship between human capital expenditure and profitability of the selected quoted manufacturing companies in Nigeria. To make clear the result of this study, the variables used in determining the effect of human capital expenditure on the profitability of the selected firms were stated below.

$\mathrm{NP}=$ Net profit

$\mathrm{SW}=$ Salaries and Wages

$\mathrm{TR}=$ Training

$\mathrm{CP}=$ Contributory Pension

$\mathrm{HT}=$ Health

4.2 The relationship between human capital expenditure and profitability of selected quoted manufacturing companies.

The variables used in the study to identify the relationship between expenditure on human capital and the profitability of selected quoted manufacturing companies are dependent and 
independent variables which formed the model designed for the study and it consist of five variables. The summary of the descriptive statistics relating to these variables are presented in table 1 below.It reveals that Net Profit (NP) shows the highest variability from the mean of $5,549,634$ with a standard deviation of $8,529,301$, this can be explained from the fact that net profit (NP) increase as a result of expensing on human capital by the organizations involved in the study. The variables have standard deviations higher than the mean which indicates the spread of the variables. Also, from table 2, the normality test was used in testing the skewness and kurtosis of the identified determinants of profitability. It shows that all the variables were normally skewed and are significant at $1 \%$ level. Table 3 shows the Shapiro Wilk test for the normality of variables used in determining the profitability of the selected firms. From the table, it shows that all the variables has mild $\mathrm{W}$ values which are close to one and are all significant at $1 \%$ level. Thus indicating how normally distributed the variables are, Shapiro Wilk is regarded as the best estimator of the variance to the usual corrected sum of squares estimator of variance (Park 2008). The test is used when the sample size is between 7 and 2000 which satisfies the sample size of this study. The distribution indicates normality when the test is positive and less than or equal to one. A significant $\mathrm{P}$ value of the $\mathrm{W}$ ratio indicates the probability that the normality is true. Therefore, if the $\mathrm{P}$ value is not significant, it means that the distribution is statistically not normally distributed.

Table 1. Descriptive statistics of Human capital efficiency

\begin{tabular}{|l|l|l|l|l|}
\hline Variables & Mean & Maximum & Minimum & Observations \\
\hline NP & 5549634. & 64261549 & 759.3650 & 98 \\
\hline CP & 253396.7 & 1757497. & 680.3560 & 98 \\
\hline TR & 229381.8 & 1581086. & 0.000000 & 98 \\
\hline SW & 2446310. & 13956840 & 346.6160 & 98 \\
\hline HT & 72622.58 & 555398.0 & 335.0000 & 98 \\
\hline
\end{tabular}

Source: Author's field report 2016 
Table 2. Skewness/Kurtosis Test of Human capital expenditure and profitability relationship

\begin{tabular}{|l|l|l|l|l|}
\hline Variables & Std. Dev. & Skewness & Kurtosis & Probability \\
\hline NP & 8529301. & 3.915178 & 24.73814 & 0.00000 \\
\hline CP & 345449.4 & 2.084749 & 7.661108 & 0.00000 \\
\hline TR & 374028.8 & 1.785743 & 5.261246 & 0.00000 \\
\hline SW & 2681400. & 1.858753 & 6.963889 & 0.00000 \\
\hline HT & 110247.7 & 2.134762 & 7.427070 & 0.00000 \\
\hline
\end{tabular}

Source: Author's field report 2016

Table 3. Shapiro-Wilk W test for normal data

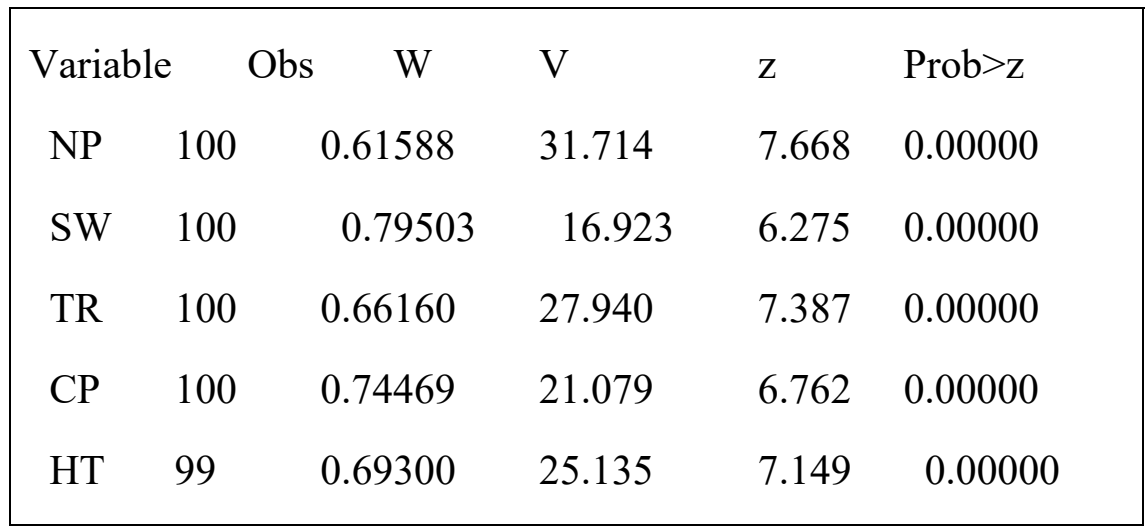

Source: Author's Field Report 2016

Table 4 explains the correlation matrices between the dependent and the independent variables. The correlation matrix helps to ascertain the extent of relationship existing amongst the dependent and independent variables on one hand as well as relationship existing amongst the independent variables on the other hand. The relationship between the dependent and independent variables is a predetermination of how the regression result would look like. From the table, the result of the correlation shows that SW, TR, CP and HT have significant positive correlation with NP indicating that NP is influenced by SW, TR, CP and HT to the tune of $39 \%, 24 \%, 40 \%$ and $52 \%$ respectively. The correlation between SW, TR, CP and HT with NP indicates that expensing on human capital enhance the performance of companies in terms of profitability. Though, all the relationship is positive but most of them are weak with the exception of health having a strong relationship. This finding corroborates Salman and Tayib (2013) who examined interaction between expenditure on human capital and financial performance of 50 public listed companies in Nigeria and provided evidence of positive interaction between the two variables. Also, it corroborates the studies of Temitope and Abdulbakar (2014) who found some of the sampled Nigeria companies having strong 
correlation and some having weak correlation. Amongst the independent variables, a significant positive correlation exists between SW, TR, CP and HT.

Table 4. Correlation Matrix for NP, SW, TR, CP and HT

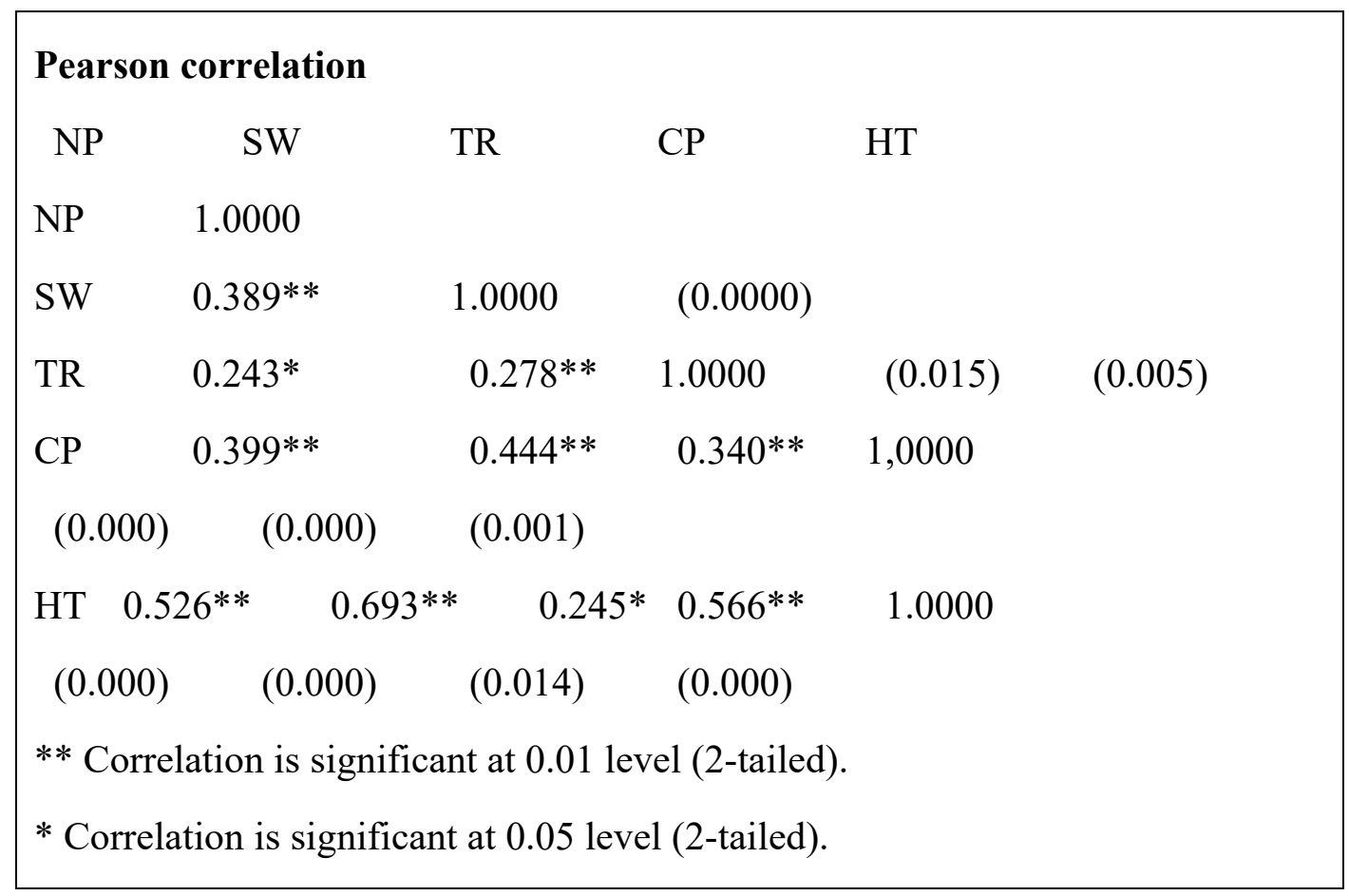

Source: Authors field report 2016

Table 5 shows the result of the regression model used in relating the joint power of SW, TR, $\mathrm{CP}$ and HT to NP. This indicates that the joint power of SW, TR, CP and HT can significantly predict NP as shown by the model $\mathrm{p}$ value of 0.0000 . This means that the model is fitted at $1 \%$. Also the joint power of SW, TR, CP and HT contributed about $33 \%$ to the total variation of NP. HT contributed more to the model with a wide variation than $\mathrm{CP}, \mathrm{TR}$ and SW as indicated by the coefficients. Individually, SW showed the weakest influence on PBT. The result also indicates that only HT can significantly predict NP at $5 \%$ level of significance. The model can be re written thus;

$$
\begin{gathered}
\mathrm{PBT}=\beta_{\mathrm{o}} \beta_{1} \mathrm{SW}+\beta_{2} \mathrm{TR}+\beta_{3} \mathrm{CP}+\beta_{4} \mathrm{HT}+\mu . \\
\mathrm{PBT}=1277892 .+0.310699_{\mathrm{sw}}+2.675213_{\mathrm{tr}}+3.451895_{\mathrm{cp}}+27.86091_{\mathrm{ht}}
\end{gathered}
$$

The equation indicates that all the explanatory variables have positive relationship with profitability. From the result, the beta value of HT (27.86091) contributed more to the profitability of the firms than the beta values of $\mathrm{CP}$, TR and SW expenditures. The result of the regression is the same with the correlation result which also has HT as having the strongest relationship with profitability. The $\mathrm{R}^{2}$ is also a little above the result of Firer and Williams (2003) who found $\mathrm{R}^{2}$ to be $30 \%$ in identifying the relationship between human capital expenditure and profitability. 
Table 5. Regression Result for the Model

\begin{tabular}{|lcl|}
\hline Variable & Co efficient & \multicolumn{1}{c|}{ P - value } \\
SW & 0.3106 & 0.4195 \\
TR & 2.6752 & 0.2042 \\
CP & 3.4519 & 0.1941 \\
HT & 27.8609 & 0.0066 \\
Constant & 1277892. & 0.2209 \\
R - squared & 0.33021 \\
Adjusted R - squared & 0.301402 \\
Model P - value & 0.00000 \\
F statistic & & 11.46239 \\
\hline
\end{tabular}

Source: Author's field report 2016

\subsection{Summary of Findings}

The findings from the studies as presented above confirm results from previous similar studies as well as also contradict some, the study found that there is positive relationship between expenditure on human capital in general and the profitability of the selected firms. This indicates that expensing on human capital has positive influence on firms' performance in terms of profitability, but despite the positive relationship very few of the companies are having their $\mathrm{p}$ value not significant. This finding is in line with the study conducted by Salim and Tayib (2013) but contradict the works of Kujansiva and Lonnquist (2007) who reported that there was no clear evidence of relationship between the two. Also, the result of the correlation shows that all the variables are having significant positive correlation with NP. Though very few of them are weak but on the whole correlation exist among the variables. This indicates that expensing on human capital enhances the performance of the selected firms in terms of profitability. This findings is consistent with Ahangar (2011) and Okwy and Christopher (2010). The result also found $\mathrm{R}^{2}$ in general to be $33 \%$. This is different from the $\mathrm{R}^{2}$ of individual organisation's classification of human capital expenditure in relation to profitability which ranges between $20 \%$ and $95 \%$.

\subsection{Conclusions}

The findings from the study revealed that human capital expenditure significantly influenced profitability of manufacturing companies quoted on the Nigeria Stock Exchange. From these findings, the study therefore conclude that companies that place more emphasis on human capital, maintaining it and treating it as a pure asset will stand apart. Expert says, "The work force is the primary way to drive revenue". Also, companies that do a proper job of making sure they have the right people at the right time at the price are going to be in the position to 
have a sustainable competitive advantage. In today's global business environment and a changing world, success is driven by talent, vision and leadership capability of employee. Companies should therefore ensure that they secure the best leadership teams for the ongoing success of the business.

\subsection{Recommendations}

Human capital expenditure is being incurred by various organizations to ensure that their profitability is enhanced for the sustainability and overall performance of their business. From the findings of the study, we recommend the followings;

2. Companies should imbibe the culture of capitalizing and reporting investment on human resources that can improve the quality and productivity. This will impact positively and significantly on their profitability and consequently on their share price value.

h4. It is important for management of quoted manufacturing companies should invest judiciously in their knowledge assets so as to attain desired profitability. This will avail organizations to attain greater success and remain competitive to achieve their long term value creation and survival goals.

6. Manufacturing companies should provide an enabling organization structure for qualified, experienced and skilled human resources to fully utilize their potentials and thus increase human capital efficiency. This will enable the organizations to achieve higher profitability, because the higher the human capital efficiency, the greater the profitability.

\section{References}

Ahangan R.G. (2011), The relationship between intellectual capital and financial performance: An empirical investigation in an Iranian company. African Journal of Business Management 5(1), 88-95.

Alan K. M. A., Altman Y., \& Roussel J. (2008). Employee Training Needs and Perceived Value of Training in the Pearl River Delta of China: A Human Capital Development Approach. Journal of European Industrial Training, 32(1), 19-31. American Institute of Certified Accountants. AICPA 1975, p.83. https://doi.org/10.1108/03090590810846548

Anuonye. (2015). Acconuting for cost and benefits of human asset. Journal of business \& Management. ISSN 2291-2002.

Baker Aledwan, (2012). The impact of basic components of intellectual capital on the profitability of Jordanian manufacturing companies. European Scientific Journal October (2014) edition, 10(28). ISSN 1857-1881.

Becker G.S. (1976). The Economic Approach to Human Behaviour. Chicago: University of Chicago Press. P. 57.

Boldizzoni, (2008). Means and ends:The ideal of capital in the west; 1500-1970, Newyork: Palgrave. Macmillian, 49. 
Chang W.S., \& Hseih, J.J. (2011). Intellectual capital a missing link? International Journal of Business and Management, 6(2), 3-12. https://doi.org/10.5539/ijbm.v6n2p3

Danish ministry of business and industry. (2004). Memorandum of understanding: Denmark Government.

Davenport T. (1999). Human Capital: What it is and why people invest in it, Jossey-Bas, Sanfrancisco. P 36

Fitzsimons P. (1999). Human capital theory and education. The encyclopedia of Education. London: Macmillian. P 113

Frank R.H., \& Bernanke B.S. (2007). Principles of Microeconomics (3rd ed.). New York: McGraw-Hill/Irwin. P.91

Ifrueze M., (2013) Impact of aggregated cost of human resources on profitability: An empirical study. Journal of business and management, ISSN 2291-1995, 3.

Ismaila Y. (2013). The relationship between Human Capital Efficiency and Financial Performance: An Empirical Investigation of Quoted Nigerian Banks. Research Journal of Finance and Accounting, 4(4). ISSN 2222-1697(paper).

Kwon D. (2010). Human capital and its measurement. OECD World Forum on "Statistics, Knowledge and policy". Busan, Korea- 27-30 October 2010. http.//www.oecdworldforum2010.org. Retrieved 7/08/2016

Mirvis P.H., \& Macy B.A. (1976). Accounting for the costs and Benefits of human Resource Development Programmes: An interdisciplinary Approach. Journal of Accounting Organisation and society, 12(3), 179-193. https://doi.org/10.1016/0361-3682(76)90022-2

Odesa O. (2014). Human Asset Accounting Treatment and Corporate Profitability Evaluation. British Journal of Economics, Finance and Management Sciences.

Organisation for Economic Co-operation and Development. (OECD) (2001). The well-being of Nations: The role of Human and Social capital. Paris: OECD.

Okwy P.O., \& Christopher C.O. (2010). Human capital Accounting and its relevance to stock Investment Decisions in Nigeria. European Journal of Economics, finance and Administrative sciences, 2, 64-76.

Rodriguez P.J., \& Loomis R.S. (2007). A New View of Institutions, Human Capital and Market Standardization. Education, Knowledge \& Economy, 1(1), 93-105. https://doi.org/10.1080/17496890601128357

Rosen H.S. (1999). Public Finance. New York: Mcgraw-Hill.

Salman R.T., \& Tayib, M (2012). Intellectual capital measurement tools. International Journal on Social Science, Economic and Art, 2(2), 19-26.

Schultz T.W. (1961). Investment in Human Capital. American Economic Review, 51, 1-17. 


\section{Macrothink}

Asian Journal of Finance \& Accounting ISSN 1946-052X

Shrader R., \& Siegal D.S. (2007). Assessing the relationship between human capital and firm performance: Evidence from technology-based new ventures. Entreprenuership Theory and Practice. 893-908. https://doi.org/10.1111/j.1540-6520.2007.00206.x

Temitope O., \& Abdulbakar S. (2014). The influence of intellectual capital efficiency on companies financial performance. International Journal of Management Studies, 6(2), 55-65.

Tseng, C., \& Goo, Y. J. (2005). Intellectual Capital and Corporate value in an emerging economy: Theoretical Studies of Taiwanese manufacturers. $R$ \& D management, 35(2), 187-201. https://doi.org/10.1111/j.1467-9310.2005.00382.x

World Economic Forum. (2015). https//www.weforum.org. Retrieved 20/08201 